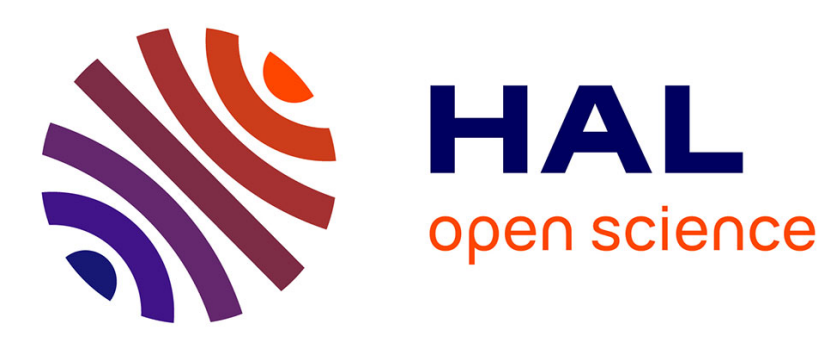

\title{
The syncretism of environmental and social responsibility with business economic performance
}

\author{
Fabien Martinez
}

\section{To cite this version:}

Fabien Martinez. The syncretism of environmental and social responsibility with business economic performance. Management of Environmental Quality: An International Journal, 2012, 23 (6), pp.597614. 10.1108/14777831211262891. hal-02887605

\section{HAL Id: hal-02887605 https://hal.science/hal-02887605}

Submitted on 9 Jul 2020

HAL is a multi-disciplinary open access archive for the deposit and dissemination of scientific research documents, whether they are published or not. The documents may come from teaching and research institutions in France or abroad, or from public or private research centers.
L'archive ouverte pluridisciplinaire HAL, est destinée au dépôt et à la diffusion de documents scientifiques de niveau recherche, publiés ou non, émanant des établissements d'enseignement et de recherche français ou étrangers, des laboratoires publics ou privés. 


\title{
The syncretism of environmental and social responsibility with business economic performance*
}

\author{
Fabien Martinez \\ BRASS Research Institute, Cardiff University, Cardiff, United Kingdom \\ 55 Park Place \\ Cardiff CF10 3AT
}

\begin{abstract}
Purpose - The present conceptual study discusses the integration of corporate social and environmental responsibility (ESR/CSR) into business strategies and operations. The objective is to propose a conceptual framework for synthesising pragmatic and constructionist theoretical discourses on ESR.

Design/methodology/approach - The paper applies the concept of syncretism - and inherent objective and subjective perspectives - to the field of ESR/CSR. A review of existing literature unfolds the construct of syncretism as a continuum integrating both systemic/pragmatic narratives and constructionist/ethnographic. The metabolism analogy is further discussed to stress the salience of ESR in determining the prospects for corporate sustainable development.

Findings - The achievement of syncretistic equilibrium is understood to occur at the intersection of constructionist and pragmatic epistemological influences. Existing research suggest that reducing or removing the external cost induced in industrial processes and exploiting marketing opportunities to signal positive ethicality of the firm are possible pathways for syncretistic equilibrium. The metabolism analogy is argued to abound with constructive implications on how businesses can provoke synergistic or symbiotic correlations between ESR and economic sustainability.

Practical implications - By integrating constructionist and pragmatic narratives into one conceptual proposition, it is hoped that this paper can lead to a better understanding of the way societal responsibility appears to business managers and, through that insight, lead to improvement in practice. Examining the extent to which metabolic processes and the functioning of the business system inspire comparable challenges can offer supportive basis for contriving effective ESR integration strategies.

Originality/value - Both constructionist (e.g. individuals' values) and systemic (e.g. business case for CSR) narratives have received considerable scholars' attention in the field of ESR/CSR. Yet, they have never been assembled into one conceptual proposition. Syncretism constitutes a new line of thinking for conceptualising the constructionist and pragmatic challenges related to the integration of ESR into business strategies and operations.
\end{abstract}

Keywords: syncretism, metabolism analogy, corporate social responsibility, corporate environmental responsibility, constructionist narratives, systemic/pragmatic narratives.

Paper type: Conceptual paper.

\section{Introduction}

The activities of businesses and their impact on society and the environment are being increasingly challenged by growth and sustainability impeding aspects inherent to the present conjuncture - i.e. financial crisis and concerns for climate change. This context generates mounting pressures on businesses to conceive innovative approaches to social and economic development.

In this paper, the integration of environmental and social concerns into business strategic agenda is investigated using the concept of syncretism as management philosophy. This philosophy advocates a broad view of CSR with the achievement of a synthesis of (possibly divergent) responsibilities as guiding principle. The syncretistic mechanism is proposed to embrace two attributes:

*Postprint of: Martinez, F. (2012). The syncretism of environmental and social responsibility with business economic performance. Management of Environmental Quality: An International Journal, 23(6), 597-614. 
(i) Systemic or pragmatic narratives reflecting the tokenistic aspiration to emphasise business core responsibilities, i.e. maximisation of firms' value, legal obligations (Carroll and Shabana, 2010; Friedman, 1970);

(ii) Constructionist or ethnographic narratives reflecting the understanding and influence of individuals on firms' strategic decisions or changes (Sonenshein, 2010), including their approach to ESR/CSR.

Narratives, according to Sonenshein (2010), "exist at both the individual and collective levels". Their examination can provide lenses through which to holistically understand strategic change implementation (Sonenshein, 2010); in particular, narratives can be examined in order to understand the application of syncretistic management practices. Syncretism proposes to venture towards equilibrium of responsibilities as a business aspiration that seeks to optimise economic and ESR performances through the coordination of top-down and bottom-up organisational mechanisms/processes.

Syncretistic equilibrium of ESR with business performance is argued in this paper to be achieved through cost management processes (elimination of waste, reduction of external cost) and exploitation of mediating variables (providing marketing opportunities). This may lead to minimise risks in day-to-day business operations and enhance competitiveness. The metabolism analogy is finally discussed to further epitomise the challenge of optimising the compatibility between green activities and economic performance.

\section{Syncretism Applied To ESR/CSR Practices}

The term syncretism has been used by anthropologist and historians throughout history as a narrative for social and cultural practices of infiltration of a supposedly pure tradition by symbols and meanings seen as belonging to other, incompatible traditions (Greenfield and Droogers, 2001; Stewart and Shaw, 1994). It originates from the earlier Greek term symkrasis - 'a mixing together, compound' (Stewart and Shaw, 1994) - and traditionally reflects the production of modified and/or new religions emerging from a contact between and interpenetration of different belief systems - e.g. Islam and Christianity (Greenfield and Droogers, 2001). Postmodern anthropologists concede that syncretic processes are now considered basic not only to religion and ritual but to the predicament of culture in general (Stewart and Shaw, 1994). In the following, syncretism is discussed as a conceptual lens through which ESR integration into business operations can be viewed and better understood.

\subsection{Objective and subjective meanings of syncretism}

Syncretism as a concept represents what Herskovits (1941) referred to as an analytical tool. Berger, Cunningham and Dumright (2007) applied syncretism to define a management philosophy, an overarching approach to business that reflects a corporate effort to appreciate and respond to the often conflicting views and values of a diverse set of stakeholders. Syncretism evokes a "combination of noneconomic and economic objectives" (Berger, et al., 2007) and is conceived as a holistic or broad view of the business case for CSR/ESR (Carroll and Shabana, 2010). It is further associated with subjective and objective meanings (Greenfield and Droogers, 2001). Comprehending the objective and subjective challenges inherent to syncretistic solutions arguably informs/predicts the capability of the firm to identify and exploit opportunities out of *Postprint of: Martinez, F. (2012). The syncretism of environmental and social responsibility with business economic performance. Management of Environmental Quality: An International Journal, 23(6), 597-614. 
the complex relationship between CSR/ESR and firm performance (Berger, et al., 2007; Carroll and Shabana, 2010). Porter and Kramer (2006) comment:

"The fact is, the prevailing approaches to CSR [often used interchangeably with ESR] are so fragmented and so disconnected from business and strategy as to obscure many of the greatest opportunities for companies to benefit society. If, instead, corporations were to analyse their prospects for social responsibility using the same frameworks that guide their core business choices [hence the applicability of syncretism as a management philosophy], they would discover that CSR can be much more than a cost, a constraint, or a charitable deed - it can be a source of opportunity, innovation, and competitive advantage."

The objective meaning of syncretism portrays the position that ESR challenges exist in reality, within capitalistic norms, external to social actors and can be subject to quantitative evaluation. That is, preserving the eco-system while producing economic progress are objective challenges inherent to industrial activities. Business environmental and social impacts are becoming increasingly scrutinised and visible, hence measurable. It is now evident that corporate confrontation with social and environmental pressures progressively leads to changes in industrial activities. Lee (2008) observes a trend in the evolution of CSR theories that indicate a tighter coupling between CSR and the organisations' financial goals. In fact, emerging thinking, influenced by growing preoccupations about the impact of collective human activity and industrial growth on the environment (Cohen and Winn, 2007; McDonough and Braungart, 2002; Tate, et al., 2010), suggests that business mission and green issues, once unrelated to each other, are now to be 'somehow' reconciled. Consequently, environmental consciousness is not to be separated from business economic purpose but rather form a newly reintegrated business culture characterised by a holistic view of ESR (Berger, et al., 2007). Syncretistic equilibrium could offer a synthesis - or synergistic combination - of corporate responsibilities, from economic, legal requirements to ethical, philanthropic social and environmental expectations and desires. This may be seen as a teleological assumption insofar as alternatively anti or non-syncretistic goals may prove to be systematically unstable on specific CSR dimensions (Devinney, 2009) - e.g. affect on profitability, alteration of the environment - and thus unsustainable. In other words, syncretistic equilibrium of ESR objectives with business economic performance is proposed to represent a natural corporate ambition, driving the quest for equitable solutions (Chester, 2010) and leading to sustainable ends - whether the link between ESR initiatives and firm performance is direct or indirect (Berger, et al., 2007; Carroll and Shabana, 2010).

A study conducted on 537 UK companies by Brammer and Millington (2008) shows that high corporate social performance - in the form of charitable giving - is compatible with and can stimulate financial performance. Albeit, on the other hand, unusually low corporate social performance is also found to generate high financial performance (Brammer and Millington, 2008), the authors give credit to the assumption that syncretism - as the infiltration of economic objectives by ethical or moral concerns (CSR/ESR activities) - can be a capitalistically viable business ambition - i.e. a form of enlightened self-interest (Carroll and Shabana, 2010). Similarly, Foote, Gaffney and Evans (2010) argue that even without direct,

*Postprint of: Martinez, F. (2012). The syncretism of environmental and social responsibility with business economic performance. Management of Environmental Quality: An International Journal, 23(6), 597-614. 
measurable empirical evidence, there is support in the literature that engaging in CSR/ESR has a significant impact on business performance.

An essential step remains to be made in research as to the degree to which this 'reconciliation' is and/or can be devised and what are the key motives. According to Chester (2010), the prospects for sustainable development are constrained to that which do not challenge accumulation, hence the salience of attempting to make sense out of the extent to which ESR initiatives impede or foster economic growth or accumulation.

The application or meaning of syncretism becomes more subjective as it comes to define the pathways to ESR integration into business activities. According to the precepts of subjectivism, social phenomena are created from the perceptions and consequent actions of social actors (Saunders, et al., 2007). Social actors, in the context of the present study, are business decision-makers and/or employees and the phenomenon under study is the role of these agents of management to generate specific approaches to ESR, otherwise referred to as the social construction of ESR initiatives. Business environmental and social engagement is thus understood to be anthropologically constructed which implies that pathways to ESR integration may be a function of proximity and/or sensibility of individual agents of management (Aguilera, et al., 2007). Qualitative investigation is hence necessary to gain insight into the motives behind individual decisions and actions. Depending on the strength of individual and collective momentum towards ESR and consistent with Herskovits' (1941) approach to syncretism, the appropriation of this term in this conceptual argument points to a distinction between fragmented approaches to ESR - whereby ESR initiatives are not integrated into business strategic agendas and applied sporadically (i.e. with no specific, consistent ESR statements or goals) - and integrative syncretism - whereby ESR initiatives are part of a strategic reflection based on long-term sustainable development and compatibilities between ESR and economic growth.

Fragmented ESR approach potentially leads to confusion and deviance, connotations given to syncretism in the nineteenth century (Stewart and Shaw, 1994). That is, lack of knowledge or expertise within firms on how to profitably apply ESR activities may constitute a source of confusion or of pessimistic impressions about whether ESR can be beneficial. This pessimism may in turn lead those who refute the idea that businesses have wider interests or responsibilities than that of making money for owners and obeying relevant (capitalistic) rules (Greenfield, 2004; Jamali and Mirshak, 2007) to such corporate deviances as detrimental affect on the environment.

On the other hand, those who acknowledge a broader, more personal conception of CSR - i.e. firms act intentionally via the actions of their members and hence bear the duties and obligations of any good person or citizen, but on a corporate scale (Goodpaster and Matthews, 2003; Hancock, 2005; Jamali and Mirshak, 2007) - may lead to corporate deviances affecting goals of profitability and economic growth. Figure 1 sketches both forms of confusions and deviances within the 'syncretistic mechanism'. The implication is that syncretism constitutes a holistic approach to ESR integration whereby risks of potential confusions and deviances may be removed.

*Postprint of: Martinez, F. (2012). The syncretism of environmental and social responsibility with business economic performance. Management of Environmental Quality: An International Journal, 23(6), 597-614. 


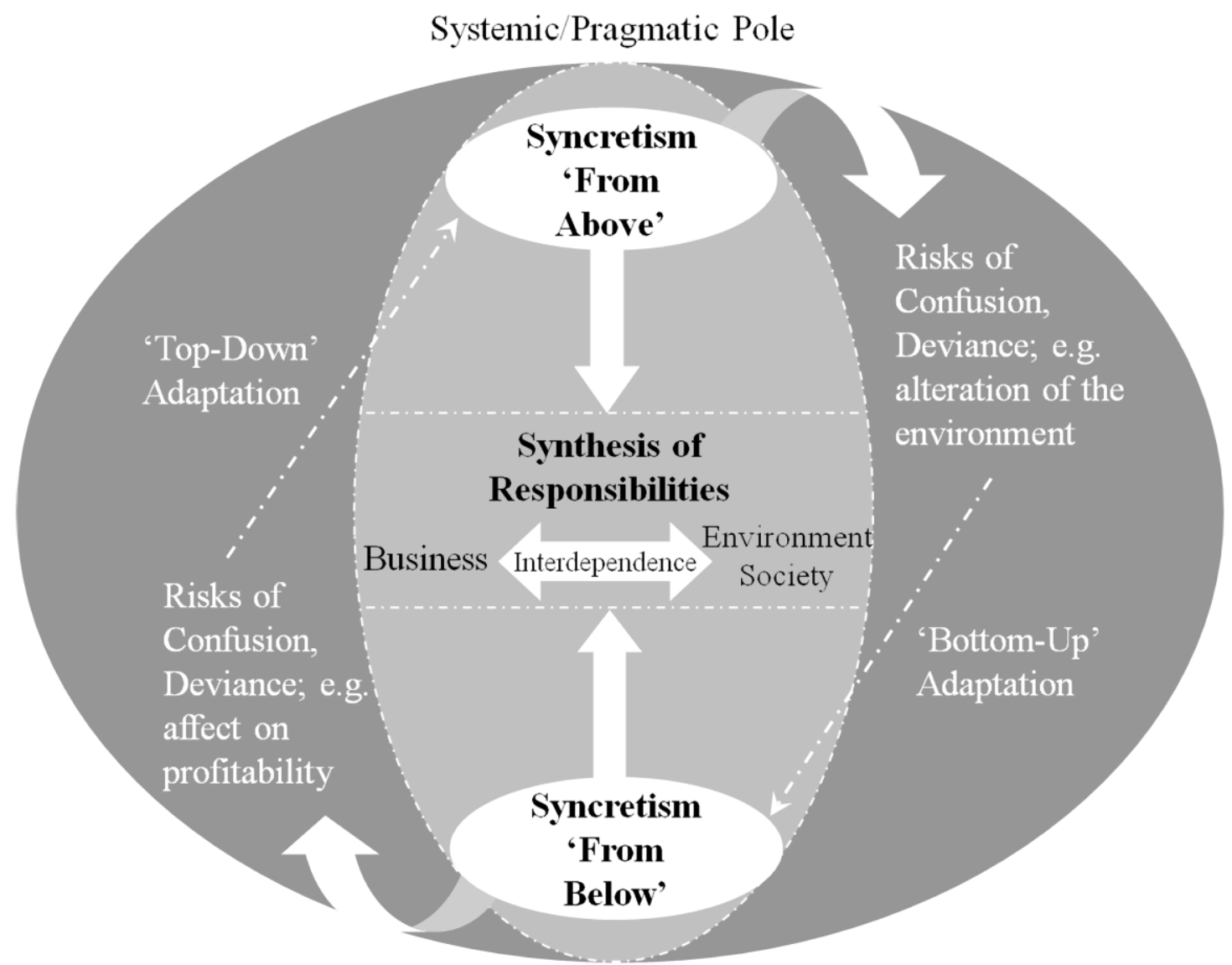

Constructionist/Ethnographic Pole

Figure 1.

Sketching two opposed ESR integration poles inherent to the 'sphere of corporate influences and responsibilities': constructionist and systemic narratives for syncretistic equilibrium

The dotted circle in Figure 1 suggests that existing knowledge is too limited to build strong certitudes as to the definition of clear pathways to the achievement of syncretism. The complexity and subjective nature of the issue facing businesses on how to integrate, measure and control ESR increases risks of deviances and confusions in application. Management decisions may not only lead to a deviation from 'primary' business responsibility of economic performance but fail to integrate sufficient concerns for their impact on the environment. Advocates of Friedman's view may consider syncretism as a possible violation of the essence of the core corporate mission of economic growth and shareholder value creation; others may adhere to the idea of a need of new business values and responsibility dimensions changing the industrial context by giving more emphasis to green issues. This debate is well reflected by the use of syncretism insofar as the term has historically been questioned about whether it is a good or bad thing - whether, for instance, it constituted "a positive achievement which strengthened and enriched Christianity" or "an entirely unprincipled jumbling together of religions" (Stewart and Shaw, 1994). Syntheses, adaptations, assemblages, incorporations or appropriations of putatively counterintuitive business ideologies - or responsibilities - are intrinsic precepts that define syncretistic equilibrium of ESR with goals of economic growth. The larger

*Postprint of: Martinez, F. (2012). The syncretism of environmental and social responsibility with business economic performance. Management of

Environmental Quality: An International Journal, 23(6), 597-614. 
circle in Figure $\mathbf{1}$ is viewed as encompassing the array of influences and responsibilities of firms with possible biases towards economic (and possibly legal) responsibilities (right side of the 'sphere') or what Carroll and Shabana (2010) refer to as the "essence of CSR" or ESR, that is ethical and/or philanthropic responsibilities (left side of the 'sphere').

An active and advanced search for compatibilities between green management and the pursuit of economic growth may indeed be a common strategy among decisionmakers of different industries in interaction or competition, outside or inside the same cluster of competition. In this paper, an objective is to discuss how syncretism applies in practice. Providing the objective and subjective interpretations discussed above, two different, possibly divergent, narratives can now be discussed.

2.2. Two 'opposed' ESR integration poles: constructionist/ethnographic and pragmatic/systemic narratives

Preuss and Dawson (2009) advocate the significance of understanding the influence of narratives on the perception of environmental issues in business. Drawing on Stewart and Shaw's (1994) discussions on religious syncretism, two possible poles can be identified and adapted to business activities. That is, discourses on CSR/ESR engagement arguably alternate between two opposed lenses: syncretism as socially constructed from the bottom of the organisation and syncretism as hierarchical encompassment, systemic development (Figure 1). These two poles reflect the challenge for syncretic equilibrium to strike a balance between the demands and rewards for non-economic versus economic criteria at the individual (micro) and organisational (meso) levels (Berger, et al., 2007).

At one pole, syncretism 'from above' posits that commitment to ESR and development of green initiatives are influenced by external forces and those who claim the capacity to 'normalise' business operations. In other words, syncretistic equilibrium is principally driven through abidance by legislation, adaptations to macroeconomic contingencies - e.g. adopting "market-based solutions" for ESR commitment (Robbins, et al., 2010) - and/or vision of top management. This approach is often referred to as top-down management practices. Syncretistic appropriations may be implemented as a response to external domination (legislation, pressures from shareholders, market volatility) or as aspirations and/or inspirations emerging from hierarchical domination. The term 'above' essentially relates to the influence of shareholders, corporate boards, CEOs (Chief Executive Officers), CFOs (Chief Financial Officers) and upper echelon business executives who are "the guardians of their companies' financial welfare and ultimately must bear responsibility for the impact of CSR on the bottom line" (Carroll and Shabana, 2010). Putative bias of these so-called 'guardians' towards tokenistic objectives of growth and share price value increase may lead to such anti-syncretistic deviances as insufficient concerns for ESR issues. This may in turn motivate pressures from below for syncretistic rehabilitations/readjustments: 'Bottom-Up' adaptation (Figure 1).

At the other pole, syncretism 'from below' refers to the development of ESR initiatives by those who are in the position of followers, subject to hierarchical power (authority) and often have first hand perspectives on the firm's environmental impact or performance - e.g. front line workers, individual agents of management (i.e. *Postprint of: Martinez, F. (2012). The syncretism of environmental and social responsibility with business economic performance. Management of Environmental Quality: An International Journal, 23(6), 597-614. 
middle managers). Seeking or provoking syncretism may be a form of resistance/conviction through active implications of citizens, front line employees, and middle managers in determining areas for improvement. Individual, voluntary citizenship initiatives in the workplace, according to Boiral (2009), can play an essential role in improving the efficacy and efficiency of environmental management practices within organisations. Sensibility - i.e. mental susceptibility leading to emotional investment - and proximity to ESR issues may be ethnographically, socially constructed; in particular, there is a need to consider the subjective meanings motivating the actions of social actors (Saunders, et al., 2007) within an organisation as potential pathway for ESR integration. Putative bias towards environmental considerations may lead to such anti-syncretistic deviances as insufficient concerns for business economic performance. Mintzberg (1983) argues that the propensity of reward firms may reap out of ESR-CSR engagement is limited and not perpetual. That is, "it pays to be good but not too good" (Mintzberg, 1983). This in turn points to syncretism from above ('Top-Down' adaptation) as an essential systemic/pragmatic adaptation to rebalance business responsibilities with a view to justifying that CSR is consistent with the firm's strategies and that it is financially sustainable (O'Sullivan, 2006).

Robbins, Hintz and Moore (2010) discuss the need to address the gap between nature and economy with recourse to a different system of valuation. They notably acknowledge the salience of non-market values and constructionism in a (dominantly) material world (Robbins, et al., 2010). Adopting the term syncretism and underlying precepts as a management philosophy in this paper allows the drawing of a more precise formulation of the mechanism of CSR/ESR integration. It further allows opening the prospects for an interdependent relation between business and environment/society. This interdependence is recognised in the literature by, inter alios, Berger et al. (2007); Carroll and Shabana (2010); and Porter and Kramer (2006). Williamson, Lynch-Wood and Ramsey (2006) observe that firms who limit their scope of responsibility to regulatory structures fail to recognise the benefits of the broader business case for CSR referred to as the syncretistic equilibrium of ESR with economic objectives. Fundamentally, understanding the syncretistic mechanism, illustrated in Figure 1, requires capturing the dichotomy 'objectivism/subjectivism' and examining the opposition 'syncretism from above/syncretism from below'. Robbins et al. (2010) concede:

"Reconciling the material reality of the environment with the powerful social constructions that influence our thinking is a major challenge."

This challenge is thus proposed to be addressed through the application of syncretistic complexes reflecting an attempt at a synthesis from divergent theoretical positions i.e. pragmatism versus constructionism.

This leads to the question of whether the syncretistic paradigm, as proposed in Figure $\mathbf{1}$, is conceivable in practice. That is, does one of the two narratives dominate the other, potentially creating premises for anti-syncretism (fragmented/asymmetric process of ESR integration)? Or can they hold equal influences? Is there a dominant trend towards anti-syncretism, whereby business decision-makers and/or policy makers would rather advocate a distribution of responsibilities between public and *Postprint of: Martinez, F. (2012). The syncretism of environmental and social responsibility with business economic performance. Management of Environmental Quality: An International Journal, 23(6), 597-614. 
private sectors? If yes, are businesses viewed to be exclusively bound to what Carroll and Shabana (2010) call "the old social contract with society" which only encompasses economic and legal responsibilities?

Future research might be designed to provide an answer to these research questions using empirical evidence to examine the challenges inherent to both poles. Now that the implications of using the term syncretism are explained, the literature review goes on to address the achievement of syncretistic equilibrium of ESR with economic growth as a purely economic and/or marketing challenge - i.e. syncretism 'from above'.

\section{Putting Syncretism into the Context of Capitalism: The Reconciliation of ESR/CSR and Economic Objectives}

Previous research from Margolis and Elfenbein (2008); Berger, Cunningham and Dumright (2007), Peloza (2006), Windsor (2006); Husted and de Jesus Salazar (2006); McWilliams, Siegel and Wright (2006); and Baron (2001) converge towards the assumption that a firm's approach to CSR does not respond to any established 'code of conduct' and is primarily driven by economic motives, i.e. CSR affordability - a strong financial performance can arguably give a company the wherewithal to contribute to society - and CSR potential return on investment. While Husted and de Jesus Salazar (2006) argue that it is "wiser" for the firm to approach CSR strategically, with return on investment as the primary objective (Margolis and Elfenbein, 2008), Carroll and Shabana (2010); and Desrocher (2010) point to the possible fallacy of assuming a systematic link between strategic options or global competitiveness and high commitment to CSR.

The term syncretism is intentionally used to translate the idea of an attempted reconciliation of divergent objectives (Berger, et al., 2007; Kollman and Stockman, 2008). That is, business environmental initiatives can arguably alter part of the firm's (immediate) profitability, a trend long assumed by scholars (Carroll and Shabana, 2010; King and Lenox, 2001); on the other hand, the quest for short term economic performance may often discard peripheral, eco-friendly activities. Carroll and Shabana (2010) emphasise the distinction between economic/financial/profitability performance - often thought by business people as something that they are doing not only for themselves, but also for society - and legal, ethical and philanthropic categories of responsibility/performance. Businesses are confronted with the challenge discussed by Porter and Kramer (2002); and Kollman and Stockman (2008) of the simultaneous and ambidextrous creation of value or economically productive uses of resources and the bold adoption and sustainability of environmentally and socially sensible actions. Managers are to directly - and/or indirectly "to appreciate the complexity of the relationship between CSR and firm financial performance" (Carroll and Shabana, 2010) - link enterprise sustainability to the creation of shareholder value (Galbreath, 2006; Hart and Milstein, 2003) and understand the (often inadvertent) environmental benefits of market forces (Desrochers, 2010). As discussed above, the pursuit of syncretistic strategies is an alternative to bilateralism whereby business goals of wealth creation are separated from or prevail against business ethics (Carroll and Shabana, 2010), arguably generating potential confusions and deviances (refer to Figure 1) - that may enhance both the firm's competitive position and its broader societal context (Porter and Kramer, 2002; Porter and *Postprint of: Martinez, F. (2012). The syncretism of environmental and social responsibility with business economic performance. Management of Environmental Quality: An International Journal, 23(6), 597-614. 
Kramer, 2006). In other words, the syncretistic balancing of economic health, social equity and environmental resilience offers a long-term integrative perspective and provides opportunities for win-win-win solutions through synergistic value creation (Falck and Heblich, 2007; Kurucz, et al., 2008).

This rationale contravenes the deeply held assumption that pro-environmental business initiatives require a trade-off in economic profitability (Cohen and Winn, 2007; Winn and Kirchgeorg, 2005). Devinney (2009) argues that corporations can never be truly socially responsible because they have conflicting virtues and vices:

“...the holy grail of CSR - 'doing well by doing good' - is an illusory goal that is noble in spirit but unachievable in practice...Corporations can be made more 'virtuous' on some dimensions, but this will invariably involve a price on other dimensions" (Devinney, 2009).

In fact, the pursuit of immediate profits and pressures for productivity improvement in industrial operations may often be incompatible with engagement in purely philanthropic environmental or social activities.

Managers of publicly traded firms, Siegle (2009) explains, have a fiduciary responsibility to adopt green management practices only if such actions complement the organisation's business and corporate-level strategies. ESR/CSR activities should be conducted, as Porter and Kramer (2006) commend, "in the way most appropriate to each firm's strategy". The decision-making process regarding ESR initiatives is to be opportunistically and strategically oriented to potentially generating tangible returns to the firm (Peloza, 2006; Siegel, 2009) and provoking a simultaneous advancement of business and environmental goals (Siegel, 2009). It can thus be suggested that the condition underpinning the moral 'tenability' of ESR is often the achievement of a syncretistic equilibrium with shareholder interests and goals of profit maximisation. ESR or CSR are viable only to the extent that corporations are convinced that there is some 'payoff' to the investment (Devinney, 2009), hence the salience of syncretism 'from above' and control and/or vision of business decision makers. As discussed in the following, the characteristics of a payoff function can be exploited through cost reduction and/or marketing opportunities inducing concrete advantages for the firm in terms of competitiveness and risk management. Zadek (2000) proposed that companies pursue CSR/ESR strategies notably to justify benefits over costs and defend their reputations.

\subsection{ESR through cost management processes}

ESR/CSR activities are presented by a number of authors (inter alios, Carroll and Shabana, 2010; Siegel, 2009; Siegel and Vitaliano, 2007) as effective solutions to lower the cost of doing business. Carroll and Shabana (2010) notably stress those CSR activities directed at the natural environment as impetuses for cost and risk reduction - e.g. realising tax benefits, avoiding strict regulation. This can be referred to as the catalytic effect of Corporate Social Performance (CSP) on Corporate Financial Performance (CFP). The argument of a positive CSP-CFP relationship is gaining increasing momentum of recognition among top managers and executives who perceive these cost savings as a bottom-line benefit of CSR (Carroll and Shabana, 2010).

*Postprint of: Martinez, F. (2012). The syncretism of environmental and social responsibility with business economic performance. Management of

Environmental Quality: An International Journal, 23(6), 597-614. 
An economic analysis of ESR begins with the realisation that such activities have emerged in response to the perception or existence of a market failure; that is, instances where there is a divergence between the private and social costs of a firms' actions (Siegel, 2009). The societal cost is defined as the private cost to the company plus an additional external cost generated by the production and delivery of a good or service that are not incurred by the producer, e.g. pollution and environmental degradation such as global warming, acid rain, and deforestation (Siegel, 2009). It follows that eco-efficient firms should strive to gain the competence needed to spot excess, unwieldy outputs of industrial activities and commend alternative processes to trigger the reduction or removal of the external cost discussed by Siegel (2009). This process requires what Vazquez et al. (2009) refer to as practices of entrepreneurship whereby a firm manages to discover, evaluate and exploit the economic opportunities present in market imperfections hindering sustainable development.

The scope of ESR extends beyond regulatory compliance to alleviate market failures - which, Desrocher (2010) argues, may rather consist of government failures - and address the inherent social costs to further encompass activities or strategies aimed at simultaneously improving environmental and economic performance (Siegel, 2009). For instance, Siegel (2009) reports the efforts of Wal-Mart and British Petroleum (prior to their catastrophic oil spill into the gulf of Mexico) in reducing pollution (partly through the reduction of greenhouse gas emissions) while enhancing their profitability. The achievement of the condition of syncretism of ESR with economic objectives is subject to the development of an industrial transformation enabling society to create a vital economy that uses radically less material and energy (Hawken, et al., 2002). The question hence arises as to whether (when and how) frugality - i.e. economic use of resources, implying the assumption that firms may improve financial performance by cutting waste (Barnett, 2007), hence reducing the external cost discussed above - can be an effective syncretistic solution to ESR integration.

Situational contingencies may affect the impact of ESR/CSR activities on firm financial performance and determine the extent to which frugal exploitation of resources can generate positive outcomes for business and environment. Barnett (2007) argues that the impact of CSR on CSP varies from one firm to the other; in particular, such variation may be attributed to factors specific to each situation. The contingent perspective advocated by Barnett (2007) contends that, although all ESR/CSR activities are not profit maximising, some forms of CSR may pay off for some firms at some points in time. In other words, there is no universal rate of return in business commitment to the environment and/or society. Nevertheless, cutting waste and considering solutions to reduce or remove the external cost induced in industrial operations (Siegel, 2009) may be viewed as generic routes to syncretism.

Carroll and Shabana (2010) argue beyond the CSP-CFP relationship to encompass the role of mediating variables for the realisation of the "full potential of CSR initiatives."

\subsection{ESR as marketing tool}

Pivato, Misani and Tencati (2008) provide empirical evidence to support the claim that trust is a central variable in many relationships between a company and its *Postprint of: Martinez, F. (2012). The syncretism of environmental and social responsibility with business economic performance. Management of Environmental Quality: An International Journal, 23(6), 597-614. 
stakeholders. It represents a mediating variable which companies strive to exploit to improve competitive performance (Pivato, et al., 2008) and lower the risk of opposition by stakeholders (Carroll and Shabana, 2010). Trust is often mediated through marketing channels signalling good corporate citizenship, especially in such areas as food or healthcare where trust is crucial in determining consumers' choice (Pivato, et al., 2008). On a similar line, engagement in ESR/CSR activities may strengthen firms' legitimacy and reputation, thereby potentially attracting consumers, investors and employees (Carroll and Shabana, 2010; Heikkurinen, 2010; Herciu and Ogrean, 2008; Kurucz, et al., 2008). Corporate reputation is defined by Heikkurinen (2010) as "an intangible way to differentiate services and products from competitors." Building positive reputation can assure the social legitimacy of organisations. It reinforces the importance of corporate citizenship driven by ecological and social consciousness (Boiral, 2009).

Mediating or demonstrating good corporate citizenship requires managerial dexterity in coordinating environmental programs - e.g. planting trees, watercourse clean-up operations, etc. - or eco-friendly features of products/services with the exploitation of marketing/communication channels - i.e. collaborating with the media, students, or academics wanting to gain a better understanding of environmental actions taken by the company. The achievement of syncretistic equilibrium can thus translate into marketing opportunities and strategies of product differentiation (Bansal and Gao, 2006). This strategic route may enable firms to either communicate superior quality (Siegel and Vitaliano, 2007) - as in the case of vertical differentiation (which occurs in a market where the several goods that are present can be ordered according to their objective quality from the highest to the lowest), e.g. given the same characteristics/features, consumers would prefer to own a more fuel-efficient vehicle (Siegel, 2009) - or appeal to specific consumer's tastes, beliefs - as in the case of horizontal differentiation (which defines products that are different according to features that can't be ordered in an objective way), e.g. consumer choice of brand is based on superior environmental performance (Siegel, 2009). While the appropriation of ESR as a quality improvement is often transparent and visible to competitors, hence restraining the possibility for first mover advantage, engagement in ESR activities can also stimulate consumer loyalty and other (intangible) benefits that are uniquely valuable to the company; an argument epitomised by Porter and Kramer (2002) in an analysis of the advantages of corporate philanthropy. Benefits that may arise from ESR include product differentiation, reputation/image enhancement, and improved relations with workers, customers, suppliers, government, and the community (Siegel, 2009).

Mc Williams and Siegel (2001) explain that an optimal level of ESR engagement can be strategically determined by cost-benefit analysis whereby the demand for ESR activities should be assessed. ESR thus constitutes a marketing tool (a sub-category of product differentiation); in particular, ethical differentiation can be used to signal a hierarchy of perceived product/service virtuousness, moral excellence. The reflection of an environmentally responsible image can enhance the firm's strategic position through internal and external differentiators from competitors as the firm becomes a privileged employer, partner and supplier, thus strengthening its brand, enlivening morale, and raising the value of its stock (Heikkurinen, 2010; Porter and Kramer, 2006). Heikurinen and Ketola (2009) note the importance of sustaining a coherent and

*Postprint of: Martinez, F. (2012). The syncretism of environmental and social responsibility with business economic performance. Management of Environmental Quality: An International Journal, 23(6), 597-614. 
stable image with firms being their identity rather than trying to manage it. In other words, developing ESR/CSR internally as an integral part of the business culture through the cognitions, emotions and aesthetic appreciations of employees (Hatch and Schultz, 2004) - is more likely to lead to desired results of business performance than focusing on the construction of an ethical image - i.e. perception of good corporate citizenship. Ketola (2007) insists on the need for pragmatic ESR integration asserting that desired results are most likely achievable if the environmental strategy is the corporate strategy. This is a fundamental principle inherent to the syncretistic management philosophy.

In terms of valuing ESR and communicating moral excellence, there is a need to address the problem of information asymmetry reflecting the potential inability of consumers to determine whether a company's internal operations adhere to their standards for ESR, not to mention the difficulty of measuring how much impact they have on the environment, i.e. how much energy they use in their homes, what the costs and benefits are of different energy solutions, or what rates of return to expect for energy efficient home enhancements (Cohen and Winn, 2007). This lack of knowledge on the part of consumers, Cohen and Winn (2007) maintain, creates a market imperfection leading consumers to make uninformed buying decisions. To alleviate information asymmetry, Siegle (2009) distinguishes between persuasive ESR advertising and informational ESR advertising. Persuasive ESR advertising attempts to positively influence consumer tastes for products with ESR attributes. Informational ESR advertising merely provides information about the ESR characteristics or ESR managerial practices of the firm, and as such, is quite similar to ESR reporting. Overall, an objective of companies is to exploit ESR/CSR initiatives as a means to convincing external stakeholders of their ethicality.

The question however arises as to the extent to which marketing ESR can provide effective syncretistic solutions. That is, the image mediated by the firm may not systematically generate desired results in terms of economic performance and environmental impact.

To recapitulate, reducing or removing the external cost induced in industrial processes (e.g. production, transport, etc) and exploiting marketing opportunities (Bansal and Gao, 2006) to signal positive ethicality of the firm are potential catalysts for ESR commitment and drivers for the achievement of syncretism. A recent insightful paper by Sully de Luque, Washburn, Waldman, and House (2008) further suggests that organisations with inspiring, transformational leaders possessing strong stakeholder values tend to have superior social and financial performance. It is thus required to comprehend the adoption of ESR as a strategic choice that is not exclusively motivated by macro-level (inter alia, population, production, distribution, regulation) and meso-level forces (institutional domains and corporate units) but also embrace micro (individual) level influences - inter alia, cognition, emotions, values, roles, status, demographic (Bansal and Gao, 2006; Turner and Daily, 2008; Waldman, et al., 2006). An increasing number of business owners and managers are actually transforming their enterprises to become more environmentally responsible because of deeply rooted beliefs and values (Bénabout and Tirole, 2010; Hawken, et al., 2002; Waldman, et al., 2006).

*Postprint of: Martinez, F. (2012). The syncretism of environmental and social responsibility with business economic performance. Management of Environmental Quality: An International Journal, 23(6), 597-614. 
The discussion now turns to the metabolism analogy which serves as a means to developing and better understanding the importance of optimising the compatibility of ESR and business economic growth as a critical challenge for sustainable development under the conditions of a capitalistic, globalised world.

\section{The Metabolism Analogy}

An analogy with living organisms and inherent metabolic processes is often, though parsimoniously, used by academics and practitioners (e.g., Desrochers, 2010; Ehrenfeld, 2007) to describe the complexity of reconciling business primary obligations of economic health and viability with ESR. Ayres (1994) spoke of "industrial metabolism", explicitly invoking a term used by biologists to describe energy and material flows in living organisms and later applied to ecological communities. The metabolism analogy essentially translates an aspiration to epitomise the need to engage businesses in building a sustainable future by transforming the situation confronting businesses to the processes inherent to the relationship of exchange between nature and humans. It proposes to think of the mechanism of business systems as analogous to the functioning of living organisms (e.g. human metabolism) - especially with regard to the exploitation of materials and energy based on the presumption that the same rules can apply to both cases (Ehrenfeld, 2003).

The predictive integration of ESR actions is often viewed through a prism that is a patchwork of non-integrated economic, social and environmental objectives. That is, business decision-makers - possibly constrained by the canonical and short-sighted ambition to achieve capitalistically constructive ends with increasing profitability as essential objective - tend to (limitedly) assimilate growth perspectives with the enhancement of financial performance. This may translate into the application of such steroidal means as aggressive marketing campaigns or massive cost cutting policies. Nevertheless, as discussed previously, it becomes increasingly salient to integrate thoughtful responses to both environmental and social pressures, whether internal (e.g. employees) or external (e.g. competitiveness, NGOs). Consistent with Everaerts and Steensels (2009), ESR is to be conceived as enabler for sustainable growth.

The absolute pursuit of immediate, foreseeable goals of profit maximisation (Jensen, 2002) holds contra-productive effects; in particular, short-term gains are often stimulated via (unsustainable) cost-cutting strategies which inspired a metabolism analogy from Koch (2007), reported in Desrocher (2010):

"It is easy to fall into the trap of a single-minded emphasis on cost reduction. Cost is only one component of value creation. If your goal is to lose weight, you could accomplish this by cutting off your leg, but that is hardly beneficial. Cost-cutting for its own sake can be just as shortsighted and can seriously damage future profitability. It is more appropriate to focus on eliminating waste."

The elimination of waste in day-to-day business operations is a laudable ESR route that is often appropriated as an eco-friendly convention under the lean production banner. Making safe and healthy use of materials in cycle of abundance (McDonough and Braungart, 2002) is an essential requisite for sustainable, long-term business growth. For example, as much as we need to modulate our nutritional habits to boost *Postprint of: Martinez, F. (2012). The syncretism of environmental and social responsibility with business economic performance. Management of Environmental Quality: An International Journal, 23(6), 597-614. 
our (biological) metabolism and reduce the risk of cardiovascular diseases, and even cancer, firms need to integrate polluting agents into their strategic agenda to internalize the social cost of pollution damage (Frosch, 1992), otherwise they will engage in excessive levels of emission of pollutants. The quest for sustainable profits as a process is thus compared to the quest for healthy nutrition. An analogy is thus proposed between processes inherent to human metabolism - i.e. metabolizing our calories into health oriented goals - and business systems - i.e. orienting the exploitation of business resources into pro-environmental goals. For example, while individuals are responsible for the self-monitoring of blood sugar status through healthy nutritional inputs, businesses have the fiduciary responsibility to sustain activities by engaging into morally tenable exploitation of natural and human resources.

Depending on the circumstances (Barnett, 2007), a firm may maximize its profits, at least in the short term, by damaging the environment and hurting people. The move toward lean working in organisations legitimates downsizing and outsourcing strategies; as a consequence, employment perspectives and on-the-job settings are increasingly deteriorating (Hawken, et al., 2002; Kinnie, et al., 1998). For example, recourse to temporary agency as a means to obtaining cheap and flexible labour increases and generates the growth of the casualisation of the work place and socioeconomic developmental impediments. In line with the scientifically proven detrimental impact of metabolic abnormalities on individuals' cognitive and mental stability, unsustainably metabolized business systems can arguably generate antidevelopmental attachment conditions - e.g. precarious employment, increasing unemployment - breeding harmful effects on mental or spiritual stability of human capital. Unsound methods of exploiting human resources can ultimately alter the social integrity of a culture in such a way that it can no longer support the happiness and improvement of its members (Hawken, et al., 2002).

Stimulating human development and integrating environmental consciousness while envisioning long-term business performance (optimising business effectiveness and efficiency) implies, to some extent, comparable challenges to sustaining a long and healthy human life. That is, both require a prudent, clinical exploitation of resources for the maintenance of the metabolism. The metabolism analogy, Ehrenfeld (2007) explains, has helped spawn the development of tools and methods for tracking the flow of materials along product life cycles, through whole economies, or along the paths of a single substance. These tools have been used in the design of product systems, or parts thereof, with lower environmental impact toward the objective of reduced material consumption.

Companies must approach ESR not exclusively as a cost but an investment for a sustainable, resilient future. The metabolism analogy abounds with potentially constructive implications on how businesses can provoke synergistic (i.e. catalytic) or symbiotic (i.e. interdependent) correlations between ESR activities and economic performance; in particular, examining the extent to which metabolic processes and the functioning of the business system - as the methodical process used as a delivery mechanism for providing specific goods or services to customers in a well defined market - inspire comparable challenges can help to reflect on the most effective ESR integration scenarios for measuring ethicality and predicting/planning long-term *Postprint of: Martinez, F. (2012). The syncretism of environmental and social responsibility with business economic performance. Management of Environmental Quality: An International Journal, 23(6), 597-614. 
sustainable business behaviour. As much as we seek advice from General Practitioners to maintain our metabolism, businesses may find it applicable to consult business experts to optimise their environmental performance and apply syncretistic solutions.

\section{Conclusion}

To reiterate, the use of syncretism in this paper allows drawing a holistic appraisal of the link between corporate economic performance and commitment to ESR/CSR. Syncretism, as management philosophy, is understood as rooted in an aspiration to optimise the level of compatibility between green/social activities and business growth perspectives; a challenge which importance and implications are epitomised through the metabolism analogy.

Syncretism poses corporate responses to ESR as a broader challenge of accounting for a complex network of constructionist (syncretism 'from below') and pragmatic (syncretism 'from above') influences (Figure 1); in particular, individuals' acts of cognition and business aspirations are argued to be dependent and interrelated part of a larger whole. To achieve this, ESR should be integrate part of the business strategic agenda and involve all business functions, units, and employees. Syncretism further contends that companies are to construct idiosyncratic interpretations of their environmental/social responsibilities and integrate them into their core operations and business strategies; as recommended for the use of ISO 26000 as ESR guidance (Moratis and Cochius, 2011).

The present study covers some of the essential benefits that may be associated to business engagement in ESR activities. That is, strategies to achieve the condition of syncretistic equilibrium are arguably justified by the possibilities to reduce the external cost identified by Siegel (2009) - thus improving productivity, reducing risks and adding value while complying with the law (Herciu and Ogrean, 2008) - and exploit marketing opportunities - thus maintaining or enhancing reputation (Herciu and Ogrean, 2008) and competitiveness (Pivato, et al., 2008).

The metabolism analogy is further discussed to illustrate the salience of adopting responsible management thinking. The discussion sheds light on environmental and social issues created and/or aggravated by businesses mired into objectives of economic growth and shareholders' value enhancement. Some consequences of corporate responsibility failings on both human capital - e.g. anti-developmental attachment conditions - and ecological capital - e.g. excessive levels of emission of pollutants - are exposed.

A proposition can be to devise future theoretical and empirical research on the basis of the syncretistic rationale and the metabolism analogy to gain deeper acumen into the mechanism and salience of corporate societal responsibility. For example, empirical work based on qualitative methods might aim at unfolding the intricate construct of ESR integration by embracing empirical considerations to both poles of the syncretistic mechanism depicted in Figure 1. In particular, further research might investigate the role of individual agents of management (micro-level influences) in constructing positive or negative green/growth correlations at the constructionist pole of the syncretistic framework.

*Postprint of: Martinez, F. (2012). The syncretism of environmental and social responsibility with business economic performance. Management of

Environmental Quality: An International Journal, 23(6), 597-614. 
Moreover, the metabolism analogy is suggested to serve as conceptual lens to promote the salience of ESR/CSR by exposing the correlation between corporate decline and corporate societal irresponsibility. In particular, future research might draw attention to the analogical correlation between human illness and unhealthy nutritional habits.

\section{References}

Aguilera, R.V., Rupp, D.E., Williams, C.A. and Ganapathi, J. (2007), "Putting the S back in Corporate Social Responsibility: a multilevel theory of social change in organizations", Academy of Management Review, Vol. 32, No. 3, pp. 836863.

Ayres, R.U. (1994), "Industrial metabolism: Theory and policy". In Ayres, R.U. and Simonis, U.E. (eds.) Industrial Metabolism United Nations University Press, Tokyo.

Bansal, P. and Gao, J. (2006), "Building the future by looking to the past: Examining research published on organizations and environment", Organization \& Environment, Vol. 19, No. 458-478.

Barnett, M.L. (2007), "Stakeholder influence capacity and the variability of financial returns to corporate social responsibility", Academy of Management Review, Vol. 32, No. 3, pp. 794-816.

Baron, D. (2001), "Private politic, corporate social responsibility and integrated strategy", Journal of Economics and Management Strategy, Vol. 16, No. 3, pp. 599-634.

Bénabout, R. and Tirole, J. (2010), "Individual and Corporate Social Responsibility", Economica, Vol. 77, No. 305, pp. 1-19.

Berger, I.E., Cunningham, P.H. and Dumright, M.E. (2007), "Mainstreaming Corporate Social Responsibility", California Management Review, Vol. 49, No. 4, pp. 132-157.

Boiral, O. (2009), "Greening the Corporation Through Organisational Citizenship Behaviors", Journal of Business Ethics, Vol. 87, No. 2, pp. 221-236.

Brammer, S. and Millington, A. (2008), "Does it pay to be different? An analysis of the relationship between corporate social and financial performance", Strategic Management Journal, Vol. 29, No. 12, pp. 1325-1343.

Carroll, A.B. and Shabana, K.M. (2010), "The Business Case for Corporate Social Responsibility: A Review of Concepts, Research and Practice", International Journal of Management Reviews, Vol. 12, No. 1, pp. 85-105.

Chester, L. (2010), "Determining the economic-environment relation: A regulationist approach", International Journal of Green Economics, Vol. 4, No. 1, pp. 1742.

Cohen, B. and Winn, M.I. (2007), "Market imperfections, opportunity and sustainable entrepreneurship", Journal of Business Venturing, Vol. 22, No. 1, pp. 29-49.

Desrochers, P. (2010), "The environmental responsibility of business is to increase its profits (by creating value within the bounds of private property rights)", Industrial and Corporate Change, Vol. 19, No. 1, pp. 161-204.

Devinney, T.M. (2009), "Is the socially responsible corporation a myth? The good, the bad, and the ugly of Corporate Social Responsibility", Academy of Management Perspectives, Vol. 23, No. 2, pp. 44-56.

*Postprint of: Martinez, F. (2012). The syncretism of environmental and social responsibility with business economic performance. Management of

Environmental Quality: An International Journal, 23(6), 597-614. 
Ehrenfeld, J.R. (2003), "Putting a Spotlight on Metaphors and Analogies in Industrial Ecology", Journal of Industrial Ecology, Vol. 7, No. 1, pp. 1-4.

Ehrenfeld, J.R. (2007), "Would Industrial Ecology Exist without Sustainability in the Background?" Journal of Industrial Ecology, Vol. 11, No. 1.

Everaerts, H. and Steensels, R. (2009), "Corporate Social Responsibility (CSR) as Enabler for Sustainable Growth", Forum Financier - Revue Bancaire et Financiaire Bank en Financiewezen, Vol. 73, No. 8, pp. 490-491.

Falck, O. and Heblich, S. (2007), "Corporate social responsibility: Doing well by doing good", Business Horizons, Vol. 50, No. 3, pp. 247-254.

Foote, J., Gaffney, N. and Evans, J. (2010), "Corporate social responsibility: Implications for performance excellence", Total Quality Management \& Business Excellence, Vol. 21, No. 8, pp. 799-812.

Friedman, M. (1970) 'A Friedman doctrine: The social responsibility of business is to increase its profits'. New York Times Magazine.

Frosch, R. (1992), "Industrial ecology: A philosophical introduction", Proceedings of the National Academy of Sciences, Vol. 89, No. 3, pp. 800-803.

Galbreath, J. (2006), "Corporate Social Responsibility Strategy: Strategic Options, Global Considerations", Corporate Governance, Vol. 6, No. 2, pp. 175-187.

Goodpaster, K. and Matthews, J. (2003) 'Can A Corporation Have a Conscience?' Harvard Business Review on Corporate Social Responsibility.

Greenfield, S.M. and Droogers, A. (2001), "Reinventing Religions: Syncretism and Transformation in Africa and The Americas", Rowman \& Littlefield, Boston Way.

Greenfield, W.M. (2004), "In the Name of Corporate Social Responsibility", Business Horizons, Vol. January-February, pp. 19-28.

Hancock, J. (2005), "Introduction: Why This Subject? Why This Book?" In Hancock, J. (ed.) Investing in Corporate Social Responsibility: A Guide to Best Practice, Business Planning and the UK's Leading Companies Kogan Page, London.

Hart, S.L. and Milstein, M.B. (2003), "Creating sustainable value", Academy of Management Executive, Vol. 17, No. 2, pp. 56-67.

Hatch, M.J. and Schultz, M. (2004), "Organisational Identity: A Reader", Oxford University Press, Oxford.

Hawken, P., Lovins, A.B. and Lovins, L.H. (2002), "Natural Capitalism. The Next Industrial Revolution", Earthscan Publications Ltd, London.

Heikkurinen, P. (2010), "Image Differentiation with Corporate Environmental Responsibility", Corporate Social Responsibility and Environmental Management, Vol. 17, No. 3, pp. 142-152.

Heikkurinen, P. and Ketola, T. (2009) 'A responsible identity: Reflections to image and reputation through awareness approach'. CCI Conference on Corporate Communications (Wroxton, UK, 5-8 June 2009.

Herciu, M. and Ogrean, C. (2008), "Interrelations between competitiveness and responsibility at macro and micro level", Management Decision, Vol. 46, No. 8, pp. 1230-1246.

Herskovits, M.J. (1941), "The myth of the Negro Past", Beacon Press, Boston, MA. Husted, B.W. and de Jesus Salazar, J. (2006), "Taking Friedman Seriously: Maximising Profits and Social Performance", Journal of Management Studies, Vol. 43, No. 1, pp. 75-91.

*Postprint of: Martinez, F. (2012). The syncretism of environmental and social responsibility with business economic performance. Management of

Environmental Quality: An International Journal, 23(6), 597-614. 
Jamali, D. and Mirshak, R. (2007), "Corporate Social Responsibility (CSR): Theory and Practice in a Developing Country Context", Journal of Business Ethics, Vol. 72, No. 3, pp. 243-262.

Jensen, M.C. (2002), "Value maximisation, stakeholder theory, and the corporate objective function", Business Ethics Quarterly, Vol. 12, No. 2, pp. 235-256.

Ketola, T. (2007) 'How to turn corporate responsibility strategies into business strategies?' European Academy of Management Conference (Ecole Centrale, HEC-Paris and INSEAD, Paris.

King, A.A. and Lenox, M.J. (2001), "Does it really pay to be green? An empirical study of firm environmental and financial performance", Journal of Industrial Ecology, Vol. 5, No. 1, pp. 105-116.

Kinnie, N., Hutchinson, S. and Purcell, J. (1998), "Downsizing: it it always lean and mean?" Personnel Review, Vol. 27, No. 4, pp. 296-311.

Koch, C.G. (2007), "The Science of Success. How Market-based Management Built the World's Largest Private Company", John Wiley \& Sons, Inc., Hoboken, NJ.

Kollman, T. and Stockman, C. (2008), "Corporate Entrepreneurship". In Wanker, C. (ed.) 21st Century Management: A Reference Handbook Sage, London.

Kurucz, E., Colbert, B. and Wheeler, D. (2008), "The business case for corporate social responsibility". In Crane, A., McWilliams, A., Matten, D., Moon, J. and Siegle, D. (eds.) The Oxford Handbook of Corporate Social Responsibility Oxford University Press, Oxford.

Lee, M.P. (2008), "A review of the theories of corporate social responsibility: its evolutionary path and the road ahead", International Journal of Management Reviews, Vol. 10, No. 1, pp. 53-73.

Margolis, J.D. and Elfenbein, H.A. (2008), "Do well by doing good? Don't count on it", Harvard Business Review, Vol. 86, No. 1, pp. 19-20.

McDonough, W. and Braungart, M. (2002), "Cradle to Cradle: Remaking the Way We Make Things", North Point Press, New York.

McWilliams, A. and Siegel, D.S. (2001), "Corporate Social Responsibility: A theory of the firm perspective", Academy of Management Review, Vol. 26, No. 1, pp. 117-127.

McWilliams, A., Siegel, D.S. and Wright, P.M. (2006), "Corporate social responsibility: strategic implications", Journal of Management Studies, Vol. 43, No. 1, pp. 1-18.

Mintzberg, H. (1983), "The case for corporate social responsibility", Journal of Business Strategy, Vol. 4, No. 2, pp. 3-15.

Moratis, L. and Cochius, T. (2011), "ISO 26000: The Business Guide to the new Standard on Corporate Social Responsibility", Greenleaf Publishing, Sheffield, UK.

O'Sullivan, K. (2006) 'Virtue rewarded: companies are suddenly discovering the profit potential of social responsibility'. $C F O$.

Peloza, J. (2006), "Using corporate social responsibility as insurance for financial performance", California Management Review, Vol. 48, No. 2, pp. 52-72.

Pivato, S., Misani, N. and Tencati, A. (2008), "The impact of corporate social responsibility on consumer trust: the case of organic food", Business Ethics: A European Review, Vol. 17, No. 1, pp. 3-12.

Porter, M.E. and Kramer, M.R. (2002), "The competitive advantage of corporate philanthropy", Harvard Business Review, Vol. 80, No. 12, pp. 56-69.

*Postprint of: Martinez, F. (2012). The syncretism of environmental and social responsibility with business economic performance. Management of

Environmental Quality: An International Journal, 23(6), 597-614. 
Porter, M.E. and Kramer, M.R. (2006), "Strategy and society: the link between competitive advantage and corporate social responsibility", Harvard Business Review, Vol. 84, No. 12, pp. 78-92.

Preuss, L. and Dawson, D. (2009), "On the Quality and Legitimacy of Green Narratives in Business: A Framework for Evaluation", Journal of Business Ethics, Vol. 84, No. S1, pp. 135-149.

Robbins, P., Hintz, J. and Moore, S.A. (2010), "Environment and Society", WileyBlackwell, Chichester, UK.

Saunders, M., Lewis, P. and Thornhill, A. (2007), "Research Methods for Business Students", Pearson Education, Harlow.

Siegel, D.S. (2009), "Green management matters only if it yields more green: an economic/strategic perspective", Academy of Management Perspectives, Vol. 23, No. 3, pp. 5-16.

Siegel, D.S. and Vitaliano, D.F. (2007), "An empirical analysis of the strategic use of corporate social responsibility", Journal of Economics and Management Strategy, Vol. 16, No. 3, pp. 773-792.

Sonenshein, S. (2010), "We're changing - or are we? Untangling the role of progressive, regressive, and stability narratives during strategic change implementation", Academy of Management Journal, Vol. 53, No. 3, pp. 477512.

Stewart, C. and Shaw, R. (1994), "Syncretism/Anti-Syncretism: The Politics of Religious Synthesis", Routledge, London.

Sully de Luque, M., Washburn, N.T., Waldman, D.A. and House, R.J. (2008), "Unrequired profit: how stakeholder and economic values relate to subordinates' perceptions of leadership and firm performance", Administrative Science Quarterly, Vol. 53, No. 4, pp. 626-654.

Tate, W.L., Ellram, L.M. and Kirchoff, J.F. (2010), "Corporate Social Responsibility Reports: A Thematic Analysis Related to Supply Chain Management", Journal of Supply Chain Management, Vol. 46, No. 1, pp. 19-44.

Turner, R.K. and Daily, G.C. (2008), "The ecosystem services framework and natural capital conservation", Environmental and Resource Economics, Vol. 39, pp. 25-35.

Vazquez, D., Brust, D., Plaza Ubeda, J. and Natenzon, C. (2009), "Environment and vulnerability: the necessity for adaptation and entrepreneurship and the key role of stakeholders". In Wanker, J. and Stoner, J. (eds.) Management Education for Global Sustainability IAP Verma, Charlotte, NC.

Waldman, D.A., Siegel, D.S. and Javidan, M. (2006), "Components of CEO transformational leadership and corporate social responsibility", Journal of Management Studies, Vol. 43, No. 8, pp. 1703-1725.

Williamson, D., Lynch-Wood, G. and Ramsey, J. (2006), "Drivers of environmental behaviour in manufacturing SMEs and the implications for CSR", Journal of Business Ethics, Vol. 67, No. 3, pp. 317-330.

Windsor, D. (2006), "Corporate Social Responsibility: Three Key Approaches", Journal of Management Studies, Vol. 43, No. 1, pp. 93-114.

Winn, M.I. and Kirchgeorg, M. (2005), "The siesta is over: a rude awakening from sustaiinability myopia". In Sanjay, S. and Starik, M. (eds.) Research in Corporate Sustainability Edward Elgar, Mass \& UK.

Zadek, S. (2000), "Doing Good and Doing Well: Making the Business Case for Corporate Citizenship".The Conference Board. New York.

*Postprint of: Martinez, F. (2012). The syncretism of environmental and social responsibility with business economic performance. Management of

Environmental Quality: An International Journal, 23(6), 597-614. 


\section{About the author}

Fabien Martinez is a $\mathrm{PhD}$ researcher in the BRASS Research Institute, Cardiff University. He can be contacted at: martinezf@cf.ac.uk.

*Postprint of: Martinez, F. (2012). The syncretism of environmental and social responsibility with business economic performance. Management of Environmental Quality: An International Journal, 23(6), 597-614. 